\title{
The Macro-Economic Reform And The Demand For Money In India
}

Basab Dasgupta, The World Bank, USA

Rangan Gupta, University of Pretoria, South Africa

\begin{abstract}
This paper is an attempt to estimate the short-run and long-run money demand functions in India during the 90's. The paper tries to closely follow the methodologies laid down in Chow (1966), Hendry (1980), Rose (1985) and Hwang (1985). The main findings of the paper are: 1) permanent income is not an appropriate representation of the scale variable, 2) the positive interest elasticity of demand for money in the short-run, 3i) limited ability of economic agents in removing disequilibrium of past period, and 4) rejection of the real adjustment hypothesis.
\end{abstract}

Keywords: Demand for Money; Error Correction Models; Partial Adjustment Models

\section{INTRODUCTION}

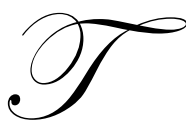

he year 1990-91 is marked as the crisis year in the context of Indian economy. An upheaval change has taken place in the macro-economic front since then and many liberalization policies and structural adjustments were made to rescue the Indian economy from its trough. Like all central banks of a developing world, the Reserve Bank of India has been playing both the developmental and regulatory role. In the context of the need to regulate money supply in line with the increased output, it was recommended to review the working of the monetary system through the system of monetary targeting with feedback. As the relationship among money, output and price holds good only over time, the monetary authority must therefore look before and after in determining the target range (Rangarajan, 1998). The money demand function became one of the most crucial guides in this context. The main objective of this study is to examine whether any behavioral changes in the money demand function did in fact take place due to the structural reforms in the Indian economy.

\section{METHODOLOGY AND DATA}

The following section of this study examines the issue of transaction motive versus the asset motive for holding money balances. This will be done basically to figure out the relative importance of permanent income and the current income in money demand decisions. We will also look into long-run and short-run behaviors of the money demand functions because "one of the major weaknesses in the available theoretical formulations of the demand functions for money seems to be the failure to distinguish between long-run or equilibrium demand and short-run demand" (Chow, 1966). During the 50's and 60's, different studies (Friedman, 1957; Meltzer, 1963; and Bruner and Meltzer, 1963) have emphasized that long-run demand for money should be treated as a durable consumer good because it yields some kind of services to the consumers; hence, permanent income or wealth is an important, and perhaps a more relevant component, in the long-run demand for money function. Along similar lines, we consider the annual money supply (M3) as a proxy of money demand, annual Gross Domestic Product at current prices as current income, three years moving average of GDP as permanent income, yearly gross capital formation as the total asset in the economy for the years 1990-91 and 1999-2000 to estimate the long-run money demand relation. In case of the short-run money demand estimation, we have taken monthly money supply (broad money or M3), monthly GDP at current prices (interpolated from the quarterly data), total monthly savings by Indians, monthly interest rates, and lag of money supply for the period April 1997 to March 2000. The reason behind incorporating the lag of money supply and savings in the estimation procedure of short-run money demand is that theoretically, demand for money is generally governed by some time lag. Moreover, following Chow's (1966) shortrun mechanism explaining the actual change in money stock, we incorporate a savings variable capturing the change 
in total assets. Then in the spirit of Hendry (1980), we estimate a money demand function using single lag for each of the relevant variables in order to eliminate the "so called nuisance of autocorrelation" (Hendry, 1980) that is prevalent in most time series data sets. For this specific model, we regress the monthly money supply of M3, on the lag value of M3, monthly GDP at current prices (interpolated from the quarterly data), the lag value of monthly GDP, monthly interest rates and the lag value of monthly interest rates. We then extend the analysis along the lines of Rose (1985) by setting up an error correction model, (the details of the specification are discussed below). The model is analyzed twice for two different values of the long-run elasticity of money demand. We also present a partial adjustment model of money demand closely imitating Hwang (1985) in order “.... to formulate a general stock adjustment model, which includes the nominal and real adjustment process as its nested subsets, and then to test each process against the general specification" (Hwang, 1985).

The study has been divided into two sections apart from the introduction, methodology and conclusion. The following section entitled Long-run Demand for Money (1990-2000) deals with the relative importance of the current income and permanent income in different formulations of the demand for money. The section named Shortrun Demand for Money (1997-2000) has three subsections (since we use the same data set). These subsections are devoted to the estimation of short-run relations of demand for money using the monthly data, the error correction models, and the partial adjustment model, respectively.

The data used in this paper has been obtained from the Annual Report of the Reserve Bank of India for the year 2001.

\section{LONG-RUN DEMAND FOR MONEY (1990-2000)}

In this section, we will discuss the relative importance of permanent income and current income on demand for money. The following variables have been used in the analysis:

LM3 Broad money or M3 at the end of the financial year in March.

LYP Three years moving averages of the GDP at current prices

LYT GDP at current price

LYAG Contribution of the agricultural sector to the GDP

LYN Contribution of the industrial sector to the GDP

LASSET Gross capital formation in the economy

LINT Annual return on the Treasury Bill of 364+ days.

Table 1: Long-Run Demand For Money Estimates In India (1990-2000)

\begin{tabular}{|c|c|c|c|c|c|}
\hline \multirow{3}{*}{ Column I } & \multicolumn{4}{|c|}{ Dependent Variable (LM3) } & \multirow[b]{2}{*}{ Column VI } \\
\hline & Column II & Column III & Column IV & Column V & \\
\hline & Model 1 & Model 2 & Model 3 & Model 4 & Model 5 \\
\hline INTERCEPT & $\begin{array}{c}-1.045929 * \\
(-3.759)\end{array}$ & $\begin{array}{c}-3.79795^{*} \\
(-3.488)\end{array}$ & $\begin{array}{c}-.873870^{*} \\
(-3.453)\end{array}$ & $\begin{array}{c}-.928759 * \\
(-3.214)\end{array}$ & $\begin{array}{l}.890455 \\
(1.140)\end{array}$ \\
\hline LYP & $\begin{array}{c}1.137696^{*} \\
(30.669)\end{array}$ & -- & -- & $\begin{array}{l}.332082 \\
(.487)\end{array}$ & -- \\
\hline LINT & $\begin{array}{c}-.015526 \\
(.164)\end{array}$ & $\begin{array}{c}-.173386 \\
(-.646)\end{array}$ & $\begin{array}{c}.046427 \\
(.524)\end{array}$ & $\begin{array}{c}.029190 \\
(.293)\end{array}$ & $\begin{array}{c}.055305 \\
(.541)\end{array}$ \\
\hline LASSET & -- & $\begin{array}{c}2.350784 * \\
(10.268)\end{array}$ & - & - & $\begin{array}{c}-1.047805^{* *} \\
(-2.366)\end{array}$ \\
\hline LYT & -- & -- & $\begin{array}{c}1.099687 * \\
(33.061)\end{array}$ & $\begin{array}{l}.779341 \\
(1.183)\end{array}$ & -- \\
\hline LYAG & -- & -- & -- & -- & $\begin{array}{c}.841575 * * \\
(2.770)\end{array}$ \\
\hline LYIN & -- & -- & -- & -- & $\begin{array}{c}.869509^{* * *} \\
(2.390)\end{array}$ \\
\hline $\mathrm{R}^{2}$ & .9935 & .9458 & .9944 & .9946 & .9957 \\
\hline Adj. $R^{2}$ & .9919 & .9323 & .9930 & .9923 & .9928 \\
\hline DW & 1.089 & .724 & .940 & .840 & 1.961 \\
\hline
\end{tabular}

Note: The numbers in the parentheses indicate the t-ratios for the test of the null hypotheses.

$(*, * *, * * *$ indicates 1,5 and 10 percent level of significance, respectively. 
In all the models, we expressed each variable in logarithmic form. Column II of Table 1 shows the result of the first model 1:

\section{LM3 = -1.0 +1.1LYP -0.01LINT}

This shows that the coefficient of permanent income, which is the income elasticity of money demand, is unitary and it is significant at the 1 percent level. The rate of interest is not significant, but the negative sign indicates the expected influence on money demand. To prove the asset motive of permanent income, we replaced permanent income by asset in model 2 :

\section{LM3 = -3.79 + 2.35LASSET -.17LINT}

The results are represented in Column III of Table 1. As in the previous model, the asset component is significant at the 1 percent level and though the interest rate has an insignificant influence, it is negatively related with the demand for money. Column IV of Table 1 represents model 3:

\section{LM3 = -0.87 +1.09LYT +0.04LINT}

This model also indicates a one-to-one relationship between current income and long-run demand for money. However, we observe that the coefficient on interest rate is positive in sign, but is insignificant. To check the relative importance of the permanent income and current income, we used both of them together as the main determinants of the long-run money demand. The result is model 4:

\section{LM3 = -0.92 + 0.77LYT +0.33LYP + 0.02LINT}

is represented by Column $\mathrm{V}$ of Table 1. Column $\mathrm{V}$ shows that though the model can explain about 99.46 percent of the variation, none of the variables are significant. However, unlike the findings of Chow (1957) and Friedman (1959), so far as relative importance is concerned, the current income has greater influence on the demand for money in the long run. To support our argument and to try and provide an explanation for such a contradiction to the well-established results, we analyze another model (model 5) with the segregated income from agriculture and industry:

\section{LM3 = 0.89 - 1.04 LASSET + 0.84LYAG +0.86 LYN +0.05LINT}

The results of the model are shown in Column VI of Table 1. From the table provided, it can be observed that the long-run money demand function is more dependent on the current income from agriculture (t value is 2.77), comparatively less than that of income from the industrial sector, and negatively on asset. One relevant argument that can be put forth in this regard is that in India, agriculture and cottage industry (around agriculture) are the main sources of income for about 70 percent of the total population and most of them are marginal farmers. Therefore, their investment in agriculture tied more closely to the past year's income and not on the permanent income. Apart from that, during this period they either sell their assets or keep it in mortgage if the expectation for the next period investment is adverse. This analysis, thus, to some extent, helps us in providing the basis for the contradictory results of model 4.

\section{SHORT-RUN DEMAND FOR MONEY (1997-2000)}

\section{Standard Approach}

The rationale for choosing this period for the estimation of the short-run demand for money is that India experienced a banking crisis during the period 1991-1994 and we wanted to exclude any prolonged or persistent perverse effect that this might have had on the chosen variables ${ }^{1}$.

\footnotetext{
${ }^{1}$ For details see Kunt and Detragiache (2001).
} 
LM3 = $\quad$ Monthly money (M3) Supply

LYT = Monthly current income (interpolated from quarterly GDP at current prices)

LLYT = $\quad$ Single period lagged monthly current income (interpolated from quarterly GDP at current prices)

$\mathbf{L Y P}=\quad$ Three period moving averages of the monthly GDP

LINT $=\quad$ Monthly interest rate

LLINT $=\quad$ Single period lagged monthly interest rate

LSAV = Monthly data on savings done by the domestic people of India in India

LLM3 = $\quad$ Single period lagged monthly money (M3) Supply

$\mathbf{L P}=\quad$ Monthly Consumer Price index

$\mathbf{L L P}=\quad$ Single period lagged monthly Consumer Price index

GLM3 = $\quad$ Growth in monthly real money (M3) Supply; LMP-LLMP

GLYT = Growth in monthly real current income (interpolated from quarterly GDP at current prices); RLYT-RLLYT

GLMYT: $\quad$ LLMP- $\theta *$ LLYT = deviation of real money supply from its long-run relationship with income (the last period error);

$\theta=$ Long-run income elasticity of money demand

where, LMP=LM3-LP; LLMP=LLM3-LLP

RLYT=LYT-LP RLLYT=LLYT-LLPGLPP= Growth in monthly Consumer Price Index; LP-LLP

Table 2: Short-Run Demand For Money Estimation In India (1997-2000)

Dependent Variable: (LM3)

Column I Column II Column III

\begin{tabular}{|l|c|c|}
\hline & Model 1 & Model 2 \\
\hline INTERCEPT & .081969 & .081441 \\
& $(1.019)$ & $-.095)$ \\
\hline LYP & -.004186 & $(-.215)$ \\
& $(-.201)$ & $.015882^{* *}$ \\
LINT & $.016141^{* *}$ & $(2.446)$ \\
& $(2.629)$ & $.988472 *$ \\
$(74.275)$ \\
\hline LLM3 & $.988509 *$ & .000595 \\
& $(75.456)$ & $(.144)$ \\
\hline LSAV & & .9979 \\
\hline Adj.R ${ }^{2}$ & & .9977 \\
\hline DW & .9979 & 1.711 \\
\hline
\end{tabular}

Note: The numbers in the parentheses indicate the t-ratio of the test of the null hypotheses.

$*, * *, * * *$ indicates 1,5 and 10 percent level of significance, respectively.

All the variables are expressed in logarithmic form. Column II of Table 2 shows the results of model 6:

\section{LM3 $=0.08-0.04 L Y P+0.01 L I N T+0.98 L L M 3$}

The result shows that in the short run, the most decisive factors are the interest rate and the last period's money supply. The effect of permanent income is negative, but insignificant. One plausible explanation for the positive interest elasticity is the fact that the interest rates were regulated and maintained well below the market rate as the Government practiced priority sector lending prior to the liberalization phase, beginning in 1992. Even after India adopted the liberalization program, interest rates were not freed completely and were to be determined by the market, but what followed as a part of the financial sector liberalization was basically a phase-wise deregulation of the interest rate structure and relaxation of the reserve requirements of the commercial banking system in an attempt to create more money through the multiplier system in the credit starved economy. The banking crisis did not help 
the cause either. It was only toward the end of 1996 and early 1997 that the interest rates were freed and the adverse effect of the crisis on expectations of economic agents started to wither out. The increased deposit rates led to an increase in deposit with households making appropriate reallocations in their portfolios, by reducing the holdings of the unproductive asset; namely, currency, Unorganized Money Market (UMM) loans, and inflation hedges. The upsurge in the deposit led to an increase in the recorded money supply, but not significantly since currency holding probably diminished. However, note that the insignificance of the relevant coefficient shows that impact of the deregulation on the money demand structure was not a major one. Moreover, it must be realized that the process of liberalization was a far-reaching and immensely extensive stretching from the current and the capital account of the external sector to the domestic real and financial sectors. Thus, it is perhaps not surprising that the economic agents took time to get accustomed to the comprehensive changes and act accordingly. Thus, such short-run distortions and deviations from long-run relationships do not seem out of the order for an economy that undergoes such phenomenal transitions in its operational structure. The results of the model 7,

\section{LM3 = 0.08 - 0.0046 LYP +0.0006 LSAV +.015LINT}

are shown in Column III of Table 2. The result vindicates our view that in the Indian context, permanent income is not the best measure for demand for money. We observe that the impact of interest rate is again positive and significant; however, that of savings, though positive, is not significant. Note that the deviation in the sign of interest elasticity from our general expectation can be explained by the same factors that were outlined above for model 6 .

\section{The Error Correction Models Of Demand For Money}

Harris (1995) rightly points out that the major reason why dynamic relationships are not always in equilibrium is because of the inability of economic agents to adjust instantaneously to new information that becomes available. Harris (1995) suggests that even if the formulated expectations were completely efficient and agents could anticipate and therefore react instantaneously to changes in the determinants, there are likely to be costs associated with the adjustment. Hence, adjustment to the new equilibrium might not be optimal or possible. The fact that these costs might be of substantial magnitude would result in current value of the dependent variable, say Y, to be determined not only by the current value of some explanatory variable, say $\mathrm{X}$, but also by past values of the same. Moreover, as $\mathrm{Y}$ evolves over time in reaction to current and past values of $\mathrm{X}$, lagged values of $\mathrm{Y}$ will also feature into the dynamicity of the short-run model. This inclusion of lagged values of $\mathrm{Y}$ as regressor is thus a way of simplifying the model, which would otherwise tend to include a large number of highly correlated past values of X. By placing restrictions on how the current value of the dependent variable reacts to the lagged values of the independent variable, in our case $\mathrm{X}_{\mathrm{t}-\mathrm{i}}(\mathrm{i}=0, \ldots \mathrm{q})$, it would be possible to reduce the number of the same entering the estimated equation at the expense of some terms involving $\mathrm{Y}_{\mathrm{t}-\mathrm{i}}(\mathrm{i}=1, \ldots \ldots \mathrm{p})$. Following Hendry (1980) and the structure outlined above, we estimate the simple single lagged regression equation described by model 9:

\section{LMP=.03+.97LLMP+.027RLYT-.006RLLYT+.01LINT+.003LLINT}

The results of model 9 are tabulated in Column II of Table 3. We observe that as in the other two estimated short-run models, the interest elasticity of the money demand is positive and the influence of the lagged value of interest rate is also positive. However, none of the interest rate coefficients are significant. The lagged value of the money supply has a positive and significant effect (significant at 1 percent level) on the dependent variable, but the income variables, both contemporaneous and lagged, have insignificant influence, with the former related positively and the latter negatively to the money demand. Note that this portrays the importance of past information for the agents in making current decisions; moreover, the results indicate the lesser importance of current income in determining the short-run money demand in the Indian context.

We observe that the long-run income elasticity of money demand evaluated from the above equation is approximately equal to unity. We extend the analysis and adopt a so-called "more suitable approach" (Harris, 1995) by formulating an Error-Correction Model (ECM) structure of the dynamic model outlined above in model 9. The ECM incorporates both short-run and long-run effects. Along the lines suggested in Rose (1985), we estimate model 10 by specifying $\theta$ (the long-run income elasticity of money demand) to be 1.0 . 
Following Rose (1985), the model specified by equation (3) was also estimated for $\theta=1 / 2$ and the regression equation looked as follows:

\section{GLM3=.053+.024GLYT-.028GLMYT+.01LINT+.003LLINT}

Table 3: Error-Correction Models For Money Demand In India (1997-2000)

\begin{tabular}{|c|c|c|c|}
\hline Column I & Column II & Column III & Column IV \\
\hline & Model 1 (LM3) & $\begin{array}{c}\text { Model 2 (GLM3) } \\
\theta=1\end{array}$ & $\begin{array}{c}\text { Model } 3 \text { (GLM3) } \\
\theta=1 / 2\end{array}$ \\
\hline INTERCEPT & $.02880(.32)$ & $.00696(.73)$ & $.05306 * * * *(1.42)$ \\
\hline LLMP & $.97202 *(51.53)$ & -- & -- \\
\hline RLYT & $.02780(.61)$ & -- & -- \\
\hline RLLYT & $-.00647(-.14)$ & -- & -- \\
\hline LINT & $.00970(.78)$ & $.00941(.78)$ & $.00998(.82)$ \\
\hline LLINT & $.00313(.19)$ & $.00235(.22)$ & $.00385(.35)$ \\
\hline GLYT & -- & $.03021(.69)$ & $.02426(.56)$ \\
\hline GLMYTi & -- & $-.02599 * * * *(-1.55)$ & $-.02847 * * * *(-1.54)$. \\
\hline $\mathrm{R}^{2}$ & .9934 & .1167 & .1158 \\
\hline Adj. $R^{2}$ & .9922 & -.0011 & -.0021 \\
\hline DW & 1.994 & 1.992 & 1.991 \\
\hline
\end{tabular}

Note: The numbers in the parentheses indicate the t-ratio of the test of the null hypotheses.

$*, * *, * * *$ indicates 1,5 and 10 percent level of significance, respectively.

The results are represented by Column IV of Table 3 . We observe that for the specified value of $q=1 / 2$, the economic agents remove a very small, nearly negligible percentage of the disequilibrium each period. Further, the sign of the coefficient of the growth rate of income in the regressions is positive, though insignificant. Also, the coefficients of the rate of interest and its lagged value have positive, but insignificant, effects and the coefficients of the regression of rate of interest and its lagged value have the same positive sign, but are insignificant. We observe that the signs of the coefficients of the variables in our model are not contingent on the specification of the long-run income elasticity. However, for the smaller the value of $\theta-1 / 2$ in this case - the growth of income positively, but insignificantly, affects the growth of the money demand and so does the interest rate.

Note that the equations were estimated without the intercept as well; but since the results were not qualitatively different, we did not report it. Note the general structure of the model used can be described as follows, supposing we have the following model to start with:

$L M 3=a+b_{1} L L M 3+c_{0} L Y T+c_{1} L L Y T+d_{0} L I N T+d_{1} L L I N T+e$

where e $\sim \operatorname{IN}\left(0, \sigma_{\mathrm{e}}{ }^{2}\right)$,

We can, however, rewrite the model as:

$(L M 3-L L M 3)=z+c_{0}(L Y T-L L Y T)-\left(1-b_{1}\right)\left(L L M 3-\theta^{*} L L Y T\right)+d_{0} L I N T+d_{1} L L I N T+e$

where $\theta=\left(c_{0}+c_{1}\right) / 1-b_{1}$. Therefore, ultimately it amounts to testing a model of the following form given by equation (3).

$G L M 3=z^{*}+a * G L Y T+b * G L M Y T i+c * L I N T+d * L L I N T+u$

where $\mathrm{u} \sim \operatorname{IN}\left(0, \sigma_{\mathrm{u}}{ }^{2}\right)$ is the white noise residual and $\mathrm{z}^{*}=\mathrm{z}, \mathrm{a}^{*}=\mathrm{c}_{0}, \mathrm{~b}^{*}=-\left(1-\mathrm{b}_{1}\right), \mathrm{c}^{*}=\mathrm{d}_{0}, \mathrm{~d}^{*}=\mathrm{d} 1$ and $\mathrm{i}=1,2$ for $\theta=1,1 / 2$, respectively. 
The results of the above model (model 10) are:

\section{GLM3=.007+.03GLYT-.026GLMYTi+.009LINT+.002LLINT}

for $\theta=1.0$ are tabulated in Column III of Table: 3 . We observe the coefficients on the growth rate of current income and lagged value of the interest rate to be positive but insignificant. The effect of the last period's error is as theory would predict. Note that the estimate of the coefficient of GLMYTi provides the information of the speed of adjustment; that is, how the variable LM3 changes in response to disequilibrium. The value (-.026) of the coefficient of GLMTYi indicates that the economic agents remove a very small percentage (since the model is in logs) - in this case, $3 \%$ of the resulting disequilibrium each period - which is perhaps indicative of the fact that individuals lay a lot of importance on past information to formulate current decisions. The positive and insignificant coefficient on the interest rate is consistent with our pre-laid explanation that emerged out of the freeing of the regulated interest rates in the economy and the above fact indicating the inability of the economic agents to remove the resulting disequilibrium.

\section{Partial Adjustment Model of Demand for Money}

Table 4: Test of The Adjustment Model And Linear Homogeneity In A Stock Adjustment Model of Demand For Money F-Test Statistic

\begin{tabular}{|c|c|c|c|}
\hline Column I & Column II & Column III & Column IV \\
\hline Test Of & F-Statistic & Conditional Test & F-Statistic \\
\hline H1 & $\mathrm{F}_{1,29}=.51(\mathrm{NR})$ & $\mathrm{H} 3 / \mathrm{H} 1$ & $\mathrm{~F}_{1,30}=.12(\mathrm{NR})$ \\
\hline $\mathrm{H} 2$ & $\mathrm{~F}_{1,29}=17.00(\mathrm{R})$ & $\mathrm{H} 4 / \mathrm{H} 1$ & $\mathrm{~F}_{1,30}=523.94(\mathrm{R})$ \\
\hline $\mathrm{H} 3$ & $\mathrm{~F}_{1,29}=.36(\mathrm{NR})$ & $\mathrm{H} 4 /(\mathrm{H} 1, \mathrm{H} 3)$ & $\mathrm{F}_{1,31}=1375.97(\mathrm{R})$ \\
\hline $\mathrm{H} 4$ & $\mathrm{~F}_{1,29}=16.30(\mathrm{R})$ & $\mathrm{H} 3 / \mathrm{H} 2$ & $\mathrm{~F}_{1,30}=1.34(\mathrm{NR})$ \\
\hline $\mathrm{H} 1, \mathrm{H} 3$ & $\mathrm{~F}_{2,29}=.31(\mathrm{NR})$ & $\mathrm{H} 4 / \mathrm{H} 2$ & $\mathrm{~F}_{1,30}=325.53(\mathrm{R})$ \\
\hline $\mathrm{H} 2, \mathrm{H} 3$ & $\mathrm{~F}_{2,29}=9.53(\mathrm{R})$ & $\mathrm{H} 4 /(\mathrm{H} 2, \mathrm{H} 3)$ & $\mathrm{F}_{1,31}=1639.06(\mathrm{R})$ \\
\hline $\mathrm{H} 1, \mathrm{H} 3, \mathrm{H} 4$ & $\mathrm{~F}_{3,29}=438.57(\mathrm{R})$ & & \\
\hline $\mathrm{H} 2, \mathrm{H} 3, \mathrm{H} 4$ & $\mathrm{~F}_{3,29}=6.85(\mathrm{R})$ & & \\
\hline
\end{tabular}

Note : $\mathrm{F}_{\mathrm{x}, \mathrm{y}}$ indicates the F-statistic with $\mathrm{x}$ and $\mathrm{y}$ as numerator and denominator degrees of freedom respectively. Also note that when $\mathrm{x}=1, \mathrm{~F}=\mathrm{t}^{2}$.

$\mathrm{R}$ and NR in the parentheses stands for the rejection and non-rejection of the null-hypotheses at 1 percent level.

The money demand literature seems to be interested in two key empirical queries. The first deals with the specification of the desired nominal stock of money, which in turn involves the choice of interest rates and the scale variable, as well as the issue regarding homogeneity of degree one of the nominal money stock with respect to the price level and income or wealth. The second involves the issue of specification of the nominal and real stock adjustment processes. Following Hwang (1985), we outline the basic structure of a general stock adjustment model, identifying various restrictions on regression parameters implied by both the nominal and real adjustment processes and by linear homogeneity of demand for money in the scale variable (income) and price. These restrictions are then tested and the results are reported in Table 4. Hwang specified a simple and commonly used functional form for the desired nominal stock of money as follows:

$\log \mathrm{M}^{*}=\theta_{0}+\theta_{1} \log \mathrm{Y}+\theta_{2} \log \mathrm{P}+\theta_{3} \log \mathrm{R}$

where $\mathrm{Y}=$ real income, $\mathrm{P}=$ price level, and $\mathrm{R}=$ interest rate. Then, by postulating a standard quadratic cost function of adjustment

$\mathrm{TC}==\alpha_{1}\{\log M *-\log M\}^{2}+\alpha_{2}\left[\left(\log M-\log M_{-1}\right)-\delta\left(\log P-\log P_{-1}\right)\right]^{2}$

and minimizing with respect to $\mathrm{M}$ after some rearrangement yields 


$$
\begin{aligned}
& \log M-\log M_{-1}=\lambda_{1}\left(\log M^{*}-\log M_{-1}\right)+\lambda_{2}\left(\log P-\log P_{-1}\right) \\
& \text { where } \lambda_{1}=\alpha_{1} /\left(\alpha_{1}+\alpha_{2}\right) \text { and } \lambda_{2}=\delta \alpha_{1} /\left(\alpha_{1}+\alpha_{2}\right)
\end{aligned}
$$

The nominal and the real adjustment hypothesis imposes the restrictions that $\lambda_{2}=0$ and $\lambda_{1}+\lambda_{2}=1$ respectively in (6). To note that $\lambda_{2}=0$ will not necessarily imply $\delta=0$ if $\alpha_{2}=0$. Thus, we need to ensure that $\alpha_{2} \neq 0$. The test of $\alpha_{2}=0$ is same as the joint test of $\lambda_{1}=1 \alpha$ nd $\lambda_{2}=0$. Combining equations (4) and (6) and rewriting in terms of real balances yields equations (7) and (8), respectively,

$$
\log (M / P)=\left\{\begin{array}{l}
\lambda_{1} \theta_{0}+\left(1-\lambda_{1}\right) \log \left(M_{-1} / P_{-1}\right)+\left(\lambda_{2}+\lambda_{1}-1\right) \log \left(P / P_{-1}\right) \\
+\lambda_{1} \theta_{1} \log Y+\lambda_{1}\left(\theta_{2}-1\right) \log P+\lambda_{1} \theta_{3} \log R
\end{array}\right\}
$$

$\log (M / P)=\beta_{0}+\beta_{1} \log \left(M_{-1} / P_{-1}\right)+\beta_{2} \log \left(P / P_{-1}\right)+\beta_{3} \log Y+\beta_{4} \log P+\lambda_{1} \theta_{3} \log R$

The linear restrictions upon the $\beta_{\mathrm{j}}$ 's of (8) to test for the nominal and the real adjustment cost and linear homogeneity hypothesis can be summarized as:

$H 1: \beta_{1}+\beta_{2}=0$

H2: $\beta_{2}=0$

H3: $\beta_{4}=0$

$H 4: \beta_{1}+\beta_{3}=1$

where $\mathrm{H} 1, \mathrm{H} 2, \mathrm{H} 3$ and $\mathrm{H} 4$ are the hypotheses of nominal adjustment, real adjustment, linear homogeneity in $\mathrm{P}$ and linear homogeneity in $\mathrm{Y}$, respectively.

We can observe from Table 4 that the test ${ }^{2}$ strongly rejects the restriction of real adjustment process, and when we have preformed a joint test of real adjustment along with the linear homogeneity of $\mathrm{P}$ and $\mathrm{Y}$, we again reject the restrictions; i.e., the rejection of $\mathrm{H} 2$ does not depend on the presence of the a priori restriction of income or price elasticity. On the other hand, we find that there is no evidence to reject the nominal adjustment hypothesis when performed separately; but when we carry out a joint test with the linear homogeneity in $\mathrm{P}$ and $\mathrm{Y}$ restrictions, we do reject the restrictions; i.e., the non-rejection of the nominal adjustment does seem to be contingent on the a priori restriction of the income and price elasticity. There is no evidence, however, to reject the unitary price elasticity (H3) when conducted separately. Note that when tested jointly with the nominal and real adjustment, we do not reject the restrictions under the former, while we reject the restrictions under the latter. However, as can be seen from the conditional tests, we do not reject $\mathrm{H} 3$ under any adjustment or the nominal adjustment. Again, under the rejected real adjustment hypothesis, we cannot reject $\mathrm{H} 3$. The unitary income elasticity (H4) is strongly rejected and under the accepted restriction of $\mathrm{H} 1$ and $\mathrm{H} 3$, it is unacceptable as well. $\mathrm{H} 4$ is also rejected in the real adjustment model with the same marginal significance level as in the nominal adjustment model. From the above discussion, we can conclude that in our data set, the real adjustment hypothesis is strongly rejected and we do not reject the already well-established empirical finding of linear homogeneity of price level of money demand. We, however, reject the unitary income elasticity hypothesis of our estimated money demand function.

\footnotetext{
${ }^{2}$ In the original paper, Hwang (1985), used a maximum likelihood estimation algorithm under the assumption that the error-term is first order auto-regressive and hence uses the likelihood ratio test statistics

to test for the conditional hypotheses. We have used the SYSLIN procedure in SAS to formulate the F-statistic for the unconditional and conditional tests.
} 


\section{CONCLUSION}

From the above analysis, it can be said that during the macro economic crisis, the current income became a crucial factor in explaining the demand for money behavior. In this regard, two explanations can be outlined. First is perhaps the high instability and frequently massive cycles in production which led people to form expectations based on the current past. Secondly, the opening up, along with the associated market orientation of the economy, made the sources of income more volatile; therefore, it was rational on part of the economic agents to formulate expectations based more on immediate past than on the trend income (the proxy for the permanent income). The error correction models indicate the very limited ability of economic agents to make adjustment to the last period disequilibrium. The positive interest elasticity in the estimated short-run demand functions and the error correction model vindicates the fact that as the interest rates were freed in a phase-wise motion, there were actually increases in money demand witnessed. We have also presented a partial adjustment model along the lines of Hwang (1985) and have strongly rejected the specification of the real stock adjustment process, which seems to have been the most commonly used stock adjustment process in the money demand literature.

\section{AUTHOR INFORMATION}

Basab Dasgupta is currently working at the World Bank in Europe and Central Asia Human Development (ECAHD) Unit. He joined the World Bank in 2005 after completing his PhD in Economics from the University of Connecticut. His areas of interest are Development Finance and Labor and Human Capital Development. E-mail: bdasgupta@worldbank.org.

Rangan Gupta is currently a Professor at the Department of Economics, University of Pretoria. After having completed his Ph.D. in May 2005 from the Department of Economics, University of Connecticut, he joined the Department of Economics, University of Pretoria, as a Senior Lecturer in August 2005 and got promoted to an Associate Professor in July 2007. He secured his BSc (Honours) degree from the R.K.M.R. College, Narendrapur, and the MSc degree from the University of Calcutta. His academic interests are mainly Monetary Theory and Policy, Business Cycles, and Time Series Econometrics. Professor Gupta has published widely in internationally acclaimed journals, including the International Business and Economics Research Journal. E-mail: Rangan.Gupta@up.ac.za.

\section{REFERENCES}

1. Bruner, Karl, and Meltzer, A.H. (1963), Predicting Velocity: Implications for Theory and Policy, Journal of Finance, Vol. 18, 319-354.

2. Demirguc-Kunt, A., and Detragiache, Enrica. (2001), Financial Liberalization and Financial Fragility, in: Caprio, G., Honohan, P., and Stiglitz E. J. eds., Financial Liberalization: How Far, How Fast?, 96-122. Cambridge University Press, Cambridge.

3. Chow, G. (1966), On the Long-run and Short-run Demand for Money, Journal of Political Economy, Vol. 74, 111-131.

4. $\quad$ Friedman, M. (1957), A Theory of Consumption Function, Princeton University Press, Princeton.

5. Harris, I. D, Richard. (1995), Using Cointegration Analysis in Econometric Modelling, Prentice Hall, New Jersey.

6. Hendry, F, David. (1980), Econometrics-alchemy or Science?, Economica, Vol. 47, 387-406.

7. Hwang, Hae-shin. (1985), Test of the Adjustment Process and Linear Homogeneity in A Stock Adjustment Model of Money Demand, The Review of Economics and Statistics, Vol. 67, 689-692.

8. Meltzer, A. H. (1963), The Demand for Money: The Evidence from Time Series, Journal of Political Economy, Vol. 71, 219-246.

9. Rangarajan, C. (1998), The Indian Economy: Essays on Money and Finance. Sangam, New Delhi.

10. Rose, K, Andrew. (1985), An Alternative Approach to the American Demand for Money, Journal of Money, Credit, and Banking, Vol. 17, 439-455. 


\section{NOTES}

